\title{
Second Primary Lung Cancer with Glottic Laryngeal Cancer as Index Tumor - A Case Report
}

\author{
Jamal Akhtar ${ }^{a}$ Rakesh Bhargava ${ }^{a}$ Mohammad Shameem $^{a}$ \\ Saurabh K. Singh ${ }^{\mathrm{a}}$ Ummul Baneen ${ }^{\mathrm{a}}$ Nafees Ahmad Khan ${ }^{\mathrm{a}}$ \\ Jassem Hassan $^{\mathrm{b}}$ Prakhar Sharma ${ }^{\mathrm{a}}$ \\ Departments of aTuberculosis and Chest Diseases, and bPathology, Jawaharlal \\ Nehru Medical College, Aligarh Muslim University, Aligarh, India
}

\section{Key Words}

Second primary lung cancer - Laryngeal squamous cell carcinoma - Routine screening

\begin{abstract}
Patients with laryngeal cancer have a high risk of developing lung cancer in the future. A patient presented with a complaint of left-sided chest pain for the last 3 months. Chest $X$-ray posterior-anterior view showed a homogeneous opacity in the left upper lung field with elevation of the diaphragm on the left side. CECT thorax revealed a heterogeneously enhancing soft tissue density mass lesion in the superior segment of the lingular lobe. On histopathological examination of the mass lesion, it was diagnosed as adenocarcinoma of the lung. About 10 months previously, the patient was treated for a laryngeal squamous cell carcinoma. Patients with laryngeal cancer should be routinely screened during follow-up with chest X-ray or CT scan for the early detection of lung cancer.
\end{abstract}

\section{Introduction}

Patients with head and neck cancers including laryngeal cancer have a high risk for developing second primary lung cancers because of the common etiological agent of smoking. Supraglottic laryngeal cancer is more commonly associated with second primary lung cancer as compared to glottic cancer. The development of second primary lung cancer adversely affects the survival rate of patients with head and neck cancer including laryngeal cancer. So, patients with head and neck cancer should be routinely screened during follow-up with chest X-ray or CT scan for the early detection of lung cancer. 


\begin{tabular}{|c|c|c|c|}
\hline $\begin{array}{l}\text { Cose Reports in } \\
\text { Oncaloy }\end{array}$ & $\begin{array}{l}\text { Case Rep Oncol 2010;3:35-39 } \\
\text { Dol: } 10.1159 / 000279320\end{array}$ & Published online: February 2, 2010 & $\begin{array}{l}\text { (c) } 2010 \text { S. Karger AG, Basel } \\
\text { ISSN } 1662-6575 \\
\text { www.karger.com/cro }\end{array}$ \\
\hline
\end{tabular}

\section{Case Report}

A 62-year-old male patient presented with a complaint of left-sided chest pain for the last 3 months. There was no history of fever, cough, shortness of breath or hemoptysis. On examination, vitals were normal. There was no lymphadenopathy, pallor or clubbing. On respiratory system examination, air entry was decreased in the left infraclavicular, suprascapular and interscapular area on auscultation. There was no abnormal finding on examination of the cardiovascular system, gastrointestinal system or CNS system.

On laboratory investigation, $\mathrm{CBC}$, blood sugar, renal function test and liver function test were within normal limits.

Chest X-ray posterior-anterior view (fig. 1) showed homogeneous opacity in the left upper lung field with elevation of the diaphragm on the left side. CECT thorax (fig. 2) was suggestive of a heterogeneously enhancing soft tissue density mass lesion in the superior segment of the lingular lobe with obliterated lingular lobe bronchus and consolidation and collapse of the anterior segment of the left upper lobe and lingular lobe. On histopathological examination of the mass lesion, it was diagnosed as a case of adenocarcinoma of the lung (fig. 3 ).

About 10 months before, the patient presented at the ENT department of our hospital with a complaint of hoarseness for the last 2 months; he was diagnosed as a case of glottic laryngeal cancer and was treated by radiotherapy to which the patient responded well. An ultrasonography of the neck done at that time showed a hyperechoic nodule in the right vocal cord (fig. 4), which on biopsy was diagnosed as well-differentiated squamous cell carcinoma (fig. 5 ).

The patient was diagnosed as a case of second primary lung adenocarcinoma with glottic laryngeal squamous cell carcinoma as index tumor. He was referred to the radiotherapy department for further management.

Written informed consent was obtained from the patient for publication of this case report and any accompanying images.

\section{Discussion}

Head and neck cancers constitute about $6 \%$ of all cancers [1]. Tobacco and alcohol are the major etiological agents associated with the development of head and neck cancer. Because of common etiological factors, patients with head and neck cancer are at risk for developing second primary malignancies at a rate of $4-7 \%$ per year [2]. Slaughter et al. [3] proposed the theory of 'field cancerization', according to which continuous exposure to common etiological agents leads to the development of second primary cancer. According to Wu et al. [4], carcinogenic agents such as tobacco and alcohol cause irreversible genetic and histologic changes which lead to the development of second primary cancer. The development of second primary cancers in patients with head and neck cancer partly affects the overall survival rate of the index tumor [5].

The lung is the most common site for the development of a second primary tumor after head and neck cancer [6]. Most second primary lung cancers occur synchronously within 24 months to index head and neck cancer [7]. Oro-hypopharynx or larynx are the most common sites of index head and neck tumor and 'squamous cell' is the most common histological type of index head and neck tumor associated with second primary lung cancer development [8]. Supraglottic laryngeal cancer is more commonly associated with second primary lung cancer as compared to glottic cancer $[9,10]$. The prognosis for second primary lung cancer in association with a head and neck carcinoma is poor because it is diagnosed in advanced stage [11] and this in turn affects the overall survival of patients with head and neck cancer.

Early detection of a second primary lung cancer is important for prolonging the survival of patients with head and neck cancer. All head and neck cancer patients should 


\begin{tabular}{c|l|l|l}
$\begin{array}{c}\text { Case Reports in } \\
\text { Oncolady }\end{array}$ & $\begin{array}{l}\text { Case Rep Oncol 2010;3:35-39 } \\
\text { D0I: 10.1159/000279320 }\end{array}$ & Published online: February 2, 2010 & $\begin{array}{l}\text { O 2010 S. Karger AG, Basel } \\
\text { ISSN 1662-6575 } \\
\text { www.karger.com/cro }\end{array}$ \\
\hline
\end{tabular}

be routinely screened using chest X-rays for early detection of a second primary lung cancer [12]. But screening by chest X-rays has failed to improve survival in patients with secondary lung cancer [12]. Screening for lung cancer by CT scan has a higher detection rate as compared to chest X-rays $[13,14]$. Chest CT or PET-CT scan should be used for early detection of second primary lung cancer, especially if the site of head and neck carcinoma are the oro-hypopharynx or larynx, if the cell type is squamous cell carcinoma, and if initial chest $\mathrm{X}$-ray findings are abnormal [8].

Fig. 1. Chest X-ray posterior-anterior view showing homogeneous opacity in the left upper lung field with an elevation of the diaphragm on the left side.

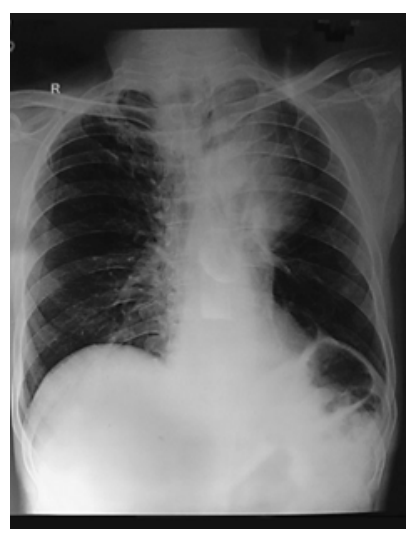

Fig. 2. CECT thorax showed a heterogeneously enhancing soft tissue density mass lesion in the superior segment of the lingular lobe with an obliterated lingular lobe bronchus with consolidation and collapse of the anterior segment of the left upper lobe and lingular lobe.

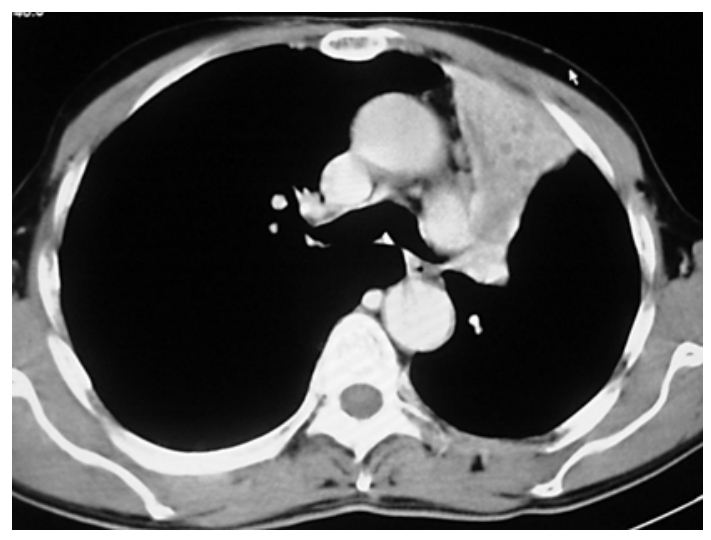




\begin{tabular}{c|l|l|l}
$\begin{array}{c}\text { Case Reports in } \\
\text { Onadogy }\end{array}$ & $\begin{array}{l}\text { Case Rep Oncol 2010;3:35-39 } \\
\text { D01: 10.1159/000279320 }\end{array}$ & & $\begin{array}{l}\text { Published online: February 2, 2010 S. Karger AG, Basel } \\
\text { ISSN 1662-6575 } \\
\text { www.karger.com/cro }\end{array}$ \\
\hline
\end{tabular}

Fig. 3. Histopathological examination of the mass lesion of the lung suggestive of adenocarcinoma of the lung.

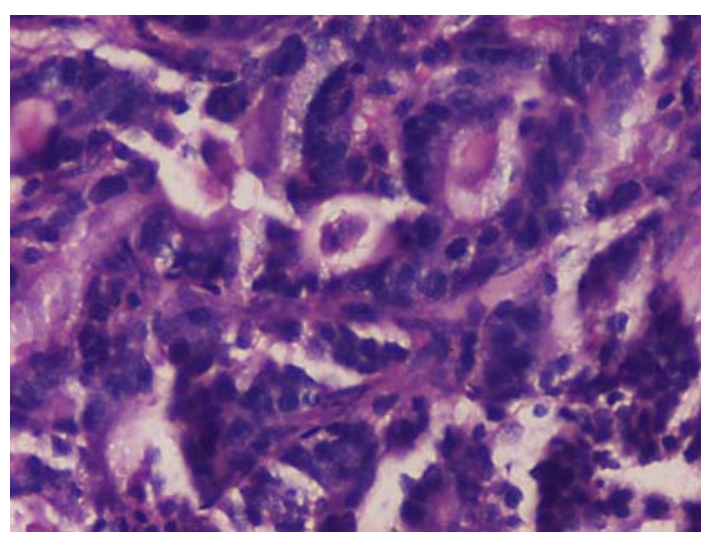

Fig. 4. Ultrasonography of the neck showing a hyperechoic nodule in the right vocal cord.

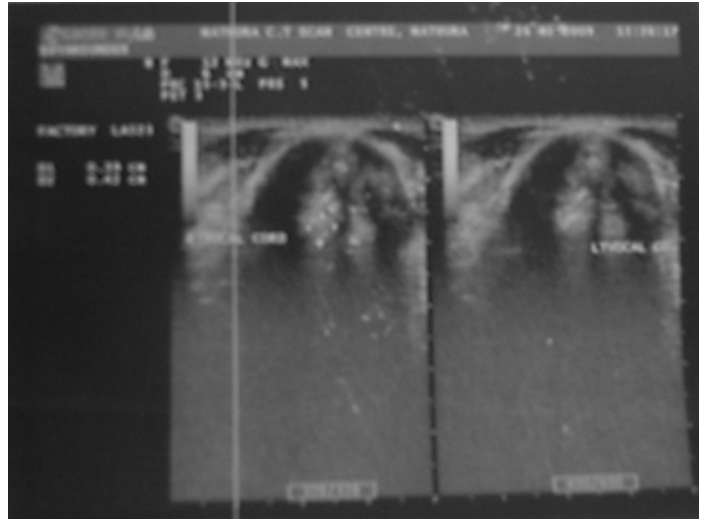

Fig. 5. Biopsy from the nodular lesion of the right vocal cord showing well-differentiated squamous cell carcinoma.

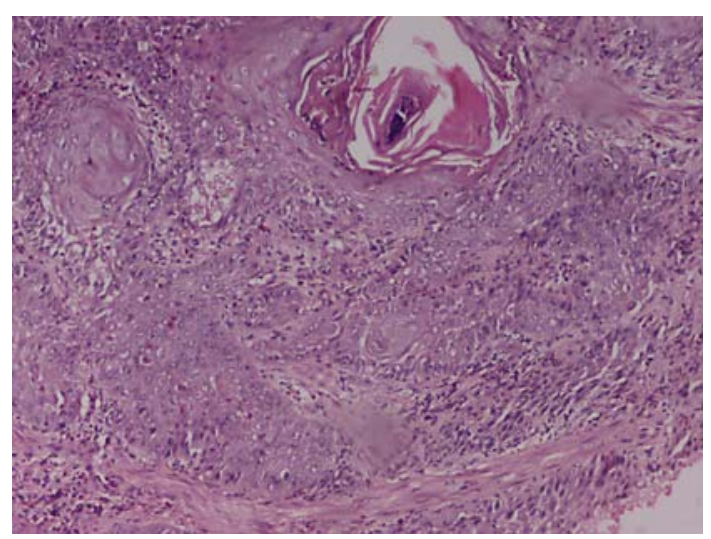




\begin{tabular}{|c|c|c|c|}
\hline $\begin{array}{l}\text { Cose Reports in } \\
\text { inceayly }\end{array}$ & $\begin{array}{l}\text { Case Rep Oncol 2010;3:35-39 } \\
\text { Dol: } 10.1159 / 000279320\end{array}$ & Published online: February 2, 2010 & \begin{tabular}{|l} 
( ) 2010 S. Karger AG, Basel \\
ISSN $1662-6575$ \\
www.karger.com/cro
\end{tabular} \\
\hline
\end{tabular}

\section{References}

1 Lefebvre JL: Current clinical outcomes demand new treatment options for SCCHN. Ann Oncol 2005;16(suppl 6):vi7-vi12.

-2 Leon X, Ferlito A, Myer CM 3rd, Saffiotti U, Shaha AR, Bradley PJ, et al: Second primary tumors in head and neck cancer patients. Acta Otolaryngol 2002;122:765-778.

-3 Slaughter DP, Southwick HW, Smejkal W: Field cancerization in oral stratified squamous epithelium; clinical implications of multicentric origin. Cancer 1953;6:963-968.

4 Wu X, Hu Y, Lippman SM: Upper aerodigestive tract cancers; in Neugut AI, Meadows AT, Robinson E (eds): Multiple Primary Cancers. Philadelphia, Lippincott, Williams and Wilkins, 1999, pp 319-346.

5 Vikram B: Changing patterns of failure in advanced head and neck cancer. Arch Otolaryngol 1984;110:564-565.

-6 Jones AS, Morar P, Phillips DE, Field JK, Husband D, Helliwell TR: Second primary tumors in patients with head and neck squamous cell carcinoma. Cancer 1995; 75:1343-1353.

-7 Hofmann HS, Neef H, Schmidt P: Primary lung cancer and extrapulmonary malignancy. Eur J Cardiothorac Surg 2007;32:653-658.

$>8$ Kim EB, Park Y, Park SJ, et al: Clinical factors related to suspected second primary lung cancer development in patients with head and neck cancer. Cancer Res Treat 2008;40:178-183.

\9 Wagenfeld DJH, Harwood AR, Byrce DP, Van Nostrand AWP, de Boer G: Second primary respiratory tract malignancies in glottic carcinoma. Cancer 1980;46:1883-1886.

10 Wagenfeld DJH, Harwood AR, Byrce DP, Van Nostrand AWP, de Boer G: Second primary respiratory tract malignant neoplasms in supraglottic carcinoma. Arch Otolaryngol 1981;107:135-137.

11 Atabek U, Mohit-Tabatabai MA, Raina S, Rush BF Jr, Dasmahapatra KS: Lung cancer in patients with head and neck cancer. Incidence and long-term survival. Am J Surg 1987;154:434-438.

12 Ritoe SC, Krabbe PF, Jansen MM, Festen J, Joosten FB, Kaanders JH, et al: Screening for second primary lung cancer after treatment of laryngeal cancer. Laryngoscope 2002;112:2002-2008.

13 Loh KS, Brown DH, Baker JT, Gilbert RW, Gullane PJ, Irish JC: A rational approach to pulmonary screening in newly diagnosed head and neck cancer. Head Neck 2005;27:990-994.

14 Henschke CI, Yankelevitz DF: CT screening for lung cancer. Radiol Clin North Am 2000;38:487-495. 